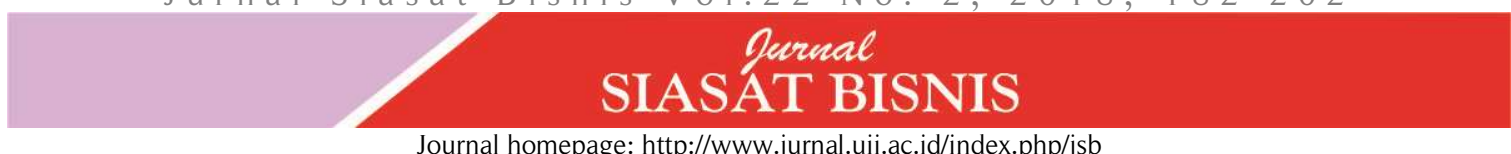

\title{
Pengaruh luas pengungkapan informasi, konsentrasi kepemilikan dan diversifikasi pada biaya modal ekuitas: studi pada perusahaan non-keuangan di indonesia
}

\author{
Ratih Kusumawardhani
}

Universitas Sarjanawiyata Tamansiswa, Yogyakarta, Indonesia

Corresponding author e-mail: ratihkusuma@ustjogja.ac.id

\begin{abstract}
This study aims to investigate the effect of disclosure, ownership concentration and diversification on the cost of equity capital among non-financial Indonesian firms using IDX data during 2010-2014 periods. This study involves both mandatory and voluntary disclosure that distinguished from previous studies in the context of Indonesia that tend to use only mandatory or voluntary disclosure. This study shows that the disclosure and the concentration of ownership significantly and negativey influence the cost of equity capital. Both mandatory and voluntary disclosure tend to have negative impact on the cost of equity capital. It turns out that the mandatory disclosure has a greater influence on the cost of equity capital than the voluntary disclosure. While, business diversification, that are measured by Herfindahl Index and the number of business segments, significantly and positively affect the cost of equity capital. Lastly, relevant theoretical and practical implications are drawn from this study.
\end{abstract}

Keywords: Disclosure, ownership concentration, business diversification, cost of equity capital

\section{Abstract}

Tujuan penelitian ini adalah untuk menguji pengaruh pengungkapan informasi, konsentrasi kepemilikan dan diversifikasi pada biaya modal ekuitas perusahaan non-keuangan di Indonesia yang terdaftar pada BEI periode 2010-2014. Penelitian ini menggunakan variabel pengungkapan yang bersifat wajib dan sukarela, hal ini menjadi pembeda dari studi sebelumnya yang cenderung berfokus pada pengungkapan wajib atau sukarela saja. Hasil studi menunjukkan bahwa pengungkapan informasi dan konsentrasi kepemilikan berpengaruh negatif terhadap biaya modal ekuitas. Kedua pengungkapan wajib dan sukarela menunjukkan hasil signifikan negatif terhadap biaya modal ekuitas, akan tetapi pengungkapan wajib memiliki pengaruh yang lebih besar dalam menurunkan biaya modal ekuitas daripada pengungkapan yang bersifat sukarela. Sedangkan, diversifikasi bisnis diukur menggunakan Herfindahl Index dan jumlah segmen menunjukkan hasil signifikan positif terhadap biaya modal ekuitas. Pembahasan mengenai impilkasi teori dan manajerial disajikan pada bagian akhir studi ini.

Kata kunci: Luas pengungkapan, struktur kepemilikan, diversifikasi bisnis, biaya modal ekuitas

JEL: G3, G32 DOI: 10.20885/jsb.vol22.iss2.art5

\section{Pendahuluan}

Penerapan tata kelola perusahaan yang baik menjadi isu dan tuntutan praktek penting dalam hal pengelolaan manajemen perusahaan, terutama di negara berkembang seperti Asia (misal Indonesia, Malaysia, Philipina, dan Thailand) dikarenakan tata kelola perusahaan di negara tersebut masih relatif buruk (Chen, Wei \& Chen, 2003). Terlebih pasca terjadinya krisis keuangan di Asia Timur pada tahun 1997 (Akhtaruddin, Hossain, Hossain \& Yao, 2009). Hal ini dikarenakan dampak krisis yang ditimbulkan tidak hanya berpengaruh terhadap keyakinan investor, tetapi juga dapat melemahkan tata kelola perusahaan sehingga konflik keagenan dan informasi asimetri semakin meningkat (Mishra, Randøy \&Jenssen, 2001; Mitton, 2002; Tan, 2000).

Mayoritas tema studi tata kelola perusahaan terdahulu di negara berkembang lebih difokuskan pada pengaruh penerapan tata kelola terhadap kinerja perusahaan (Bhagat \& Bolton, 
2008). Dalam konteks Indonesia, studi yang sama juga telah banyak dilakukan (Anggraini, 2006; Guna \& Herawaty, 2010; Nuswandari, 200; Sayidah, 2007; Sriwedari, 2012; Sukamulja, 2004; Wati, 2012). Sementara studi tata kelola perusahaan di Indonesia ditinjau dari perspektif keagenan dan biaya modal ekuitas masih relatif sedikit (Khomsiyah, 2003; Mardiyah, 2002).

Fokus penelitian ini adalah untuk menguji pengaruh mekanisme tata kelola terhadap biaya modal ekuitas. Biaya modal ekuitas adalah keuntungan yang disyaratkan atas investasi yang dilakukan oleh pemilik perusahaan (Brigham, 2011). Hasil studi terdahulu menemukan bentuk atau mekanisme tata kelola yang dapat menurunkan biaya modal ekuitas yaitu melalui luas pengungkapan informasi perusahaan (Chen et. al., 2003; Mitton, 2002) dan konsentrasi kepemilikan (Denis, Denis, \& Yost, 2002). Selain kedua mekanisme tersebut, strategi diversifikasi yang dilakukan perusahaan juga mampu menurunkan biaya modal ekuitas (Aleson \& Escuer, 2002; Berger \& Ofek, 1995; Chen \& Ho, 2000; Palich, Cardinal \& Miller, 2000).

Terkait luas pengungkapan informasi perusahaan, studi terdahulu menunjukkan dua temuan yang berbeda antara hubungan luas pengungkapan dan biaya modal ekuitas. Pertama, luas pengungkapan dapat menurunkan konflik keagenan dan infomasi asimetri antara pemilik dan pengelola sehingga keuntungan yang disyaratkan pemilik juga semakin rendah (Botosan \& Plumlee, 2000; Jensen \& Meckling, 1976). Selain itu, luas pengungkapan juga dapat melindungi investor dari perlakuan yang tidak adil sekaligus sebagai penyedia informasi untuk kepentingan analisis investasi (Wolk et al., 2001) bahkan investor bersedia membayar secara premium bagi perusahaan yang melakukan pengungkapan informasi secara luas (Mitton, 2002).

Pendapat kedua dikaitkan dengan teori keagenan yang mendukung hubungan positif antara luas pengungkapan dan biaya modal ekuitas. Peningkatan pengungkapan akan meningkatkan volatilitas yang akibatnya dapat meningkatkan resiko pengelolaan perusahaan yang dilakukan manajemen, resiko berbanding lurus dengan keuntungan yang disyaratkan oleh investor, selanjutnya investor akan menginformasikan ke pasar sehingga menjadi salah satu penentu faktor pergerakan harga saham tersebut (Berton, 1994; Coles \& Loewenstein, 1988). Hasil studi tersebut sejalan dengan yang dilakukan oleh Merton (1987), bahwa ketidakmerataan distribusi pengungkapan informasi perusahaan akan meningkatkan informasi asimetri. Belum adanya kesepakatan temuan pada studi terdahulu mengenai hubungan antara luas pengungkapan informasi dan biaya modal ekuitas mendorong peneliti untuk melakukan penelitian dengan tema tersebut dalam konteks perusahaan Indonesia. Meskipun penelitian serupa telah dilakukan di Indonesia (Khomsiyah, 2003; Mardiyah, 2002), namun fokus penelitian mereka hanya pada luas pengungkapan yang bersifat sukarela. Sebagai pembeda, penelitian ini menggunakan variabel luas pengungkapan yang bersifat wajib dan sukarela.

Mekanisme kedua yang dapat menurunkan konflik keaganen adalah struktur kepemilikan perusahaan (Demsetz \& Lehn, 1985; Denis et al. 2002). Struktur kepemilikan perusahaan yang optimal merupakan salah satu bentuk tata kelola perusahaan yang dapat menyamakan kepentingan pemilik dan pengelola perusahaan (Denis et al, 2002). Salah satu aspek penting struktur kepemilikan menurut Zhuang, Edwards \& Capulong (2000) adalah melalui kepemilikan yang terkonsentrasi, dengan kepemilikan terkonsentrasi maka pemilik dapat melakukan pengawasan yang lebih luas dan memilki hak suara yang lebih besar, sehingga dapat mengurangi perilaku oportunistik pengelola perusahaan. Studi penelitian yang dilakukan Brickley, Lease \& Smith (1988); Collins \& Huang (2010); McConnell \& Sarvaes (1990); Pound (1988) menyebutkan bahwa konsentrasi kepemilikan akan menurunkan biaya modal ekuitas yang ditanggung oleh perusahaan. Temuan tersebut diperkuat oleh studi yang dilakukan Demsetz \& Lehn (1985), bahwa konsentrasi kepemilikan menghilangkan konflik kepentingan antara pemilik dan pengelola karena hak suara yang dimiliki pemilik dapat mengendalikan kebijakan manajemen. Akan tetapi, selain memberikan dampak positif, konsentrasi kepemilikan juga menimbulkan beberapa dampak negatif. Pertama, pemilik mayoritas dapat melakukan ekspropriasi terhadap pemilik minoritas atau terjadinya konflik keagenan tipe 2 (Claessens, Djankov, Fan \& Lang, 2000). Kedua, kepemilikan tidak terdiversifikasi menyebabkan resiko yang ditanggung pemilik menjadi 
Pengaruh luas pengungkapan informasi, konsentrasi kepemilikan dan diversifikasi pada biaya modal ekuitas: studi pada perusahaan non-keuangan di indonesia

lebih besar (Shleifer \& Vishny, 1997). Ketiga, menimbulkan biaya keagenan yang terdiri dari biaya monitoring, biaya bonding dan residual loss (Jensen \& Meckling, 1976).

Perbedaan hasil studi terdahulu mengenai hubungan antara kepemilikan terkonsentrasi dan biaya modal ekuitas mendorong peneliti untuk mengkonfirmasi apakah struktur kepemilikan terkonsentrasi berpengaruh positif atau negatif terhadap biaya modal ekuitas pada perusahaan di Indonesia. Lebih lanjut, kondisi di Indonesia juga memiliki perlindungan investor yang masih lemah, sehingga rawan terjadi konflik antara pengelola dan pemilik dikenal dengan konflik keagenan tipe 1, dan antara pemilik mayoritas dan pemilik minoritas atau konflik keagenan tipe 2 (Claessens et al., 2000). Sehingga isu struktur kepemilikan perusahaan dikaitkan dengan biaya modal ekuitas menjadi isu penelitian yang menarik.

Mekanisme ketiga yang dapat digunakan untuk menurunkan biaya modal ekuitas adalah diversifikasi perusahaan (Elyasiani \& Wang, 2009). Karakteristik perusahaan di Indonesia cenderung memiliki tingkat diversifikasi yang rendah atau struktur kepemilikannya terkonsentrasi dan saat ini mengarah pada konglomerasi (Khanna \& Yafeh, 2007). Salah satu alternatif bagi perusahaan yang akan memperluas operasi bisnisnya adalah melalui diversifikasi bisnis (Patrisia, 2007). Menurut Khanna \& Palepu (1997), strategi diversifikasi di negara berkembang lebih tepat dilakukan daripada fokus karena adanya perbedaan konteks institusional.

Studi terdahulu menunjukkan hasil kontradiksi hubungan antara strategi diversifikasi dan biaya modal ekuitas. Pendapat pertama menyebutkan bahwa diversifikasi perusahaan secara industrial maupun internasional dapat menurunkan resiko pemilik, karena resiko tersebar pada beberapa segmen bisnis sehingga biaya modal ekuitas menurun (Elyasiani \&Wang, 2009). Manfaat lain diversifikasi yaitu terciptanya sinergi, keunggulan kekuatan pasar, berkurangnya resiko bisnis serta kemudahan memperoleh dana pinjaman (Aleson \& Escuer, 2002; Berger \& Ofek, 1995; Chen \& Ho, 2000; Palich, et al. 2000).

Sedangkan, pendapat kedua menyatakan bahwa tren konglomerasi pada perusahaan yang melakukan diversifikasi industri maupun lintas negara mengalami kegagalan dalam melakukan pengawasan perusahaan dan hanya menciptakan permasalahan baru (Denis et al.,1999). Dampak negatif lainnya adalah meningkatkan biaya logistik dan distribusi, meningkatkan informasi asimetri antara lain biaya koordinasi dan kontrol perusahaan, serta biaya akibat inefisiensi dalam pengalokasian dana (Mackey \& Barney, 2006; Shin \& Stulz, 1998).

Studi terdahulu mengenai diversifikasi bisnis telah banyak dilakukan di negara maju dengan karakter kepemilikan perusahaan yang cenderung tersebar dan memiliki perlindungan hukum yang baik bagi pemilik (Misal: Nachum, 2004). Sedangkan, penelitian ini dilakukan pada perusahaan di Indonesia yang memiliki karakteristik kepemilikan terkonsentrasi dan perlindungan hukum yang masih lemah bagi investor. Sehingga hasil penelitian ini diharapkan akan memberikan hasil yang berbeda dengan penelitian terdahulu pada konteks di negara-negara maju.

Penjelasan tentang mekanisme tata kelola perusahaan, strategi diversifikasi dan biaya modal ekuitas menjadi faktor yang membedakan fokus studi ini dengan studi terdahulu. Tujuan utama dari studi ini adalah untuk menguji pengaruh luas pengungkapan perusahaan, konsentrasi kepemilikan serta diversifikasi bisnis perusahaan terhadap biaya modal ekuitas pada perusahaan di Indonesia. Sehingga penelitian ini diharapkan dapat menjawab pertanyaan "apakah luas pengungkapan perusahaan, konsentrasi kepemilikan, dan diversifikasi bisnis mempengaruhi biaya modal ekuitas pada perusahaan di Indonesia?"

\section{Reviu Literatur dan Pengembangan Hipotesis}

\section{Luas Pengungkapan Informasi dan Biaya Modal Ekuitas}

Luas pengungkapan informasi yang dilakukan oleh perusahaan terdiri dari pengungkapan yang bersifat wajib dan sukarela (Botosan, 1997). Dalam konteks Indonesia, pengungkapan wajib berdasarkan kriteria yang disyaratkan oleh Badan Pengawas Pasar Modal atau BAPEPAM. Sedangkan 
pengungkapan sukarela memuat informasi tentang transaksi pasar modal, pembagian saham, shareholder litigation, biaya-biaya dan informasi peramalan perusahaan yang dilakukan oleh manajer (Healy \& Palepu, 2001). Pengungkapan informasi yang bersifat sukarela bermanfaat bagi perusahaan karena dapat menjadi alternatif solusi untuk memecahkan masalah dalam laporan keuangan (Leadbetter, 2000). Hal ini karena mampu menutup gap antara nilai instrinsik perusahaan dengan nilai pasar saat ini (Schultze, 2004).

Studi mengenai konflik informasi asimetri dan luas pengungkapan informasi pada negara berkembang telah banyak dilakukan, termasuk di Indonesia. Misal studi yang dilakukan oleh Gulo (2000) menguji tentang pengaruh luas pengungkapan sukarela perusahaan terhadap biaya modal ekuitas perusahaan, penelitian tersebut menunjukkan adanya hubungan negatif antara pengungkapan sukarela dan biaya modal ekuitas perusahaan. Penelitian yang sama juga dilakukan oleh Mardiyah (2002), menguji pengaruh informasi asimetri dan pengungkapan informasi terhadap biaya modal, hasil penelitian tersebut menunjukkan bahwa pengungkapan informasi yang dilakukan oleh perusahaan dapat menurunkan biaya modal.

Pengungkapan informasi perusahaan memiliki manfaat yang besar terutama pada perusahaan-perusahaan di negara berkembang (Misalnya Indonesia dan Thailand) yang memiliki karakteristik kepemilikan terkonsentrasi dan perlindungan hukum yang rendah (La Porta, Lopez-deSilanes \& Shleifer, 1999). Hal ini dikarenakan dengan tipe kepemilikan yang terkonsentrasi tetapi tidak adanya perlindungan hukum yang kuat, maka besar kemungkinan terjadi manipulasi oleh pengelola (manajer) (Leuz \& Verrecchia, 2000). Sehingga, keberadaan luas pengungkapan informasi dapat berperan besar dalam menurunkan biaya modal ekuitas dan konflik keagenan pada negara berkembang (Chen et. al., 2003). Selain itu, luas pengungkapan juga dapat menjadi jembatan saat terjadinya informasi asimetri antara pemilik dengan pengelola maupun pemilik mayoritas dengan minoritas (Balling et. al., 2005). Sehingga hipotesis yang diajukan adalah:

$\mathrm{H}_{1}$ : Luas pengungkapan informasi berpengaruh negatif pada biaya modal ekuitas.

\section{Konsentrasi Kepemilikan Perusahaan dan Biaya Modal Ekuitas}

Pasar modal di negara Asia Timur dan Asia Tenggara memiliki tipe struktur kepemilikan yang cenderung terkonsentrasi pada satu atau sedikit pemegang saham besar (blockholders) dan perlindungan terhadap investor yang masih lemah, sehingga rawan terjadinya konflik antara pemilik dan pengelola, hal ini berbeda dengan perusahaan di negara maju yang memiliki ciri kepemilikan tersebar dan juga perlindungan hukum yang baik (Claessens et al., 2000; La Porta et. al., 1999). Dalam tipe kepemilikan terkonsentrasi, pemilik dapat melakukan kontrol yang lebih luas terhadap kinerja manajer agar sesuai dengan kepentingan pemilik, sehingga berdampak pada penurunan konflik keagenan dan informasi asimetri dan berpengaruh pada penurunan biaya modal ekuitas (Denis et al., 1999). Temuan tersebut diperkuat oleh Jensen \& Meckling (1976) serta Shleifer \& Vishny (1997) yang menyatakan bahwa pemegang saham besar baik individu maupun institusional memiliki insentif yang besar untuk mengawasi pengelola perusahaan (manajer) terutama dalam hal pengambilan kebijakan agar tidak merugikan pemilik. Selain itu, juga memiliki hak suara yang besar untuk mengganti pengelola apabila terjadi moral hazard sehingga biaya keagenan dan biaya modal ekuitas dapat menurun (Ashbaugh, Collins \& LaFond, 2004).

Sejalan dengan hasil studi yang dilakukan oleh Demsetz \& Lehn (1985), bahwa konsentrasi kepemilikan dapat menghilangkan konflik antara pemilik dan manajer yang disebabkan karena adanya perbedaan kepentingan, pemilik mempunyai hak monitoring/pengawasan yang besar terhadap pengelola. Pengawasan terhadap pengelola penting untuk dilakukan sebagai dampak adanya pemisahan kepemilikan dan kontrol perusahaan (Jensen \& Meckling, 1976). Terlebih hasil studi yang dilakukan Eisendhart (1998) menyatakan bahwa teori agensi dilandasi atas tiga sifat manusia, salah satunya manusia memiliki sifat oportunistik dan mementingkan diri sendiri. Hal tersebut sejalan dengan hasil studi yang dilakukan oleh Zhuang et. al. (2000) menunjukkan bahwa 
Pengaruh luas pengungkapan informasi, konsentrasi kepemilikan dan diversifikasi pada biaya modal ekuitas: studi pada perusahaan non-keuangan di indonesia

pengawasan dilakukan dengan tujuan untuk mengurangi perilaku oportunistik dari manajer sehingga dapat mengurangi biaya modal ekuitas.

Struktur kepemilikan yang terkonsentrasi selain memberikan manfaat juga memiliki resiko yaitu terjadinya ekspropriasi yang dilakukan oleh pemilik mayoritas terhadap pemilik minoritas (konflik keagenan tipe 2) (Morck et. al., 2005). Tindakan ekspropriasi ini merugikan pemilik minoritas (Young, et al., 2008). Salah satu cara agar tidak terjadi ekspropriasi pemilik minoritas, maka struktur kepemilikan harus tersebar (Ashbaught et al., 2004). Akan tetapi, kondisi tersebut justru dapat meningkatkan konflik antara pemilik dan pengelola (konflik keagenan tipe 1) dan juga resiko terjadinya ekspropriasi yang dilakukan pengelola (manajer) terhadap pemilik semakin bertambah (Jensen \& Meckling, 1976; Young, Peng, Ahlstrom, Bruton \& Jiang, 2008). Studi tersebut sejalan dengan yang dilakukan oleh Demsetz \& Lehn (1985); Shleifer \& Vishny (1986), bahwa kecenderungan pengelola melakukan ekspropriasi meningkat dan kebijakan yang diambil hanya menguntungkan pengelola saja. Hal ini dikarenakan kurangnya pengawasan terhadap perilaku pengelola dan hak suara yang dimiliki pemilik rendah (Jensen \& Meckling, 1976; Morck, Wolfenzon \& Yeung, 2005). Oleh karena itu, konsekuensi dari kepemilikan tidak terkonsentrasi (tersebar) menyebabkan pemilik harus mengeluarkan biaya yang besar untuk membayar profesional guna melakukan pengawasan, namun pemilik saham mayoritas memiliki kecenderungan tidak bersedia melakukan hal tersebut (Ashbaught et al., 2004).

Konsentrasi kepemilikan memiliki manfaat yang besar dalam mengurangi konflik antara pemilik dan pengelola, akan tetapi pada pasar modal di negara berkembang memiliki kelemahan dalam hal perlindungan hukum. Pemerintah Indonesia sadar mengenai hal tersebut, oleh karena itu pemerintah mengeluarkan ketentuan yang berlaku di pasar modal Indonesia, yang diatur dalam Undang-Undang Pasar Modal N0.8 Tahun 1995, Pasal 87 (2) mengatakan bahwa "Setiap Pihak yang memiliki sekurang-kurangnya 5\% (lima perseratus) saham Emiten atau Perusahaan Publik wajib melaporkan kepada Bapepam atas kepemilikan dan setiap perubahan kepemilikannya atas saham perusahaan tersebut." Ketentuan kepemilikan 5\% dianggap sudah memiliki keleluasaan hak suara dalam memonitor kinerja manajer agar bertindak sesuai dengan kepentingan pemilik.

Berdasar hasil studi terdahulu dan kondisi perlindungan hukum pasar modal di Indonesia, maka keberadaan kepemilikan terkonsentrasi dapat memberikan keuntungan bagi pemilik perusahaan atas investasi saham yang mereka lakukan. Demikian juga hasil studi yang dilakukan oleh Collins \& Huang (2010), yang menyatakan bahwa terdapat pengaruh negatif antara kepemilikan dengan biaya modal ekuitas. Sehingga hipotesis yang diajukan adalah:

$\mathrm{H}_{2}$ : Konsentrasi kepemilikan berpengaruh negatif pada biaya modal ekuitas.

\section{Diversifikasi Bisnis dan Biaya Modal Ekuitas}

Trend diversifikasi bisnis pada perusahaan di negara berkembang semakin tinggi (misal: India dan Pakistan, Brazil dan Chile, Indonesia dan Thailand, Korea, dan lain-lain), dan juga pada beberapa perusahaan di negara maju (misal: Itali dan Swedia) (Khanna \& Yafeh, 2007). Diversifikasi merupakan salah satu bentuk keputusan strategis di level korporat, yang menunjukkan adanya proses memasuki suatu industri baru yang berbeda dengan industri perusahaan guna menciptakan produk baru (Hill \& Jones, 2009).

Perusahaan melakukan strategi diversifikasi salah satunya bertujuan untuk portofolio resiko perusahaan dengan menginvestasikan dana pada beberapa bisnis (Rumelt, 1974). Sejalan dengan hasil studi Elyasiani \& Wang (2009); Mansi \& Reeb (2002), bahwa diversifikasi perusahaan secara industri maupun internasional dapat menurunkan resiko pemilik perusahaan, karena resiko tersebar pada beberapa segmen sehingga dapat menurunkan biaya modal ekuitas. Resiko perusahaan berbanding lurus dengan keuntungan yang akan diperoleh pemilik, saat resiko kecil maka pemilik dalam menetapkan keuntungan yang disyaratkan juga rendah atau dengan kata lain biaya modal ekuitas rendah (Brigham, 2011). 
Ditinjau dari teori agensi, Jensen \& Meckling (1976) menyatakan bahwa evaluasi keagenan hubungan antara pemilik dan pengelola merupakan hal yang paling penting terlebih bagi perusahaan yang melakukan strategi diversifikasi. Hal ini dikarenakan, diversifikasi memiliki kecenderungan tata kelola yang buruk karena sebagai dampak tindakan pengelola yang hanya mementingkan keuntungan bagi dirinya sendiri (Aggarwal \& Samwick 2003; Rose \& Shepard 1997). Oleh karena itu, penting bagi perusahaan yang melakukan strategi diversifikasi untuk menerapkan mekanisme tata kelola yang baik agar mencegah terjadinya konflik keagenan (Tsai et al., 2009). Sekalipun pemilik memiliki kewenangan untuk melakukan penggantian manajer disaat tidak dapat bekerja dengan baik (Anderson et al., 2000).

Disisi lain, berdasar hasil studi sebelumnya apabila diversifikasi dapat dikelola dengan baik maka dapat meningkatkan sinergi, keunggulan kekuatan pasar, berkurangnya resiko bisnis karena tersebar pada beberapa segmen bisnis yang saling berbeda serta kemudahan memperoleh dana pinjaman (Aleson \& Escuer, 2002; Amit \& Livnat 1988, Berger \& Ofek, 1995; Chen \& Ho, 2000; Palich, et al. 2000). Studi tersebut diperkuat dengan temuan yang dilakukan oleh Amihud \& Lev (1981) dan Stulz (1990), menyatakan bahwa diversifikasi bisnis berhubungan negatif dengan biaya keagenan. Hal ini dikarenakan manfaat strategi bisnis yaitu perusahaan dapat melakukan aktivitas subsidi silang pendanaan kepada berbagai divisi lain yang berkinerja buruk dan tidak mampu mengelola pendanaan internalnya dengan baik tanpa harus melibatkan pihak lain dalam memenuhi pendanaan, sehingga mampu menurunkan konflik keagenan dan informasi asimetri.

Diversifikasi bisnis di negara berkembang berbeda dengan di negara maju (Lins \& Servaes, 2004). Pada perusahaan di negara maju, diversifikasi bisnis hanya merugikan perusahaan, hal ini karena biaya yang dikeluarkan lebih besar daripada manfaat yang akan diterima. Sejalan dengan hasil studi yang dilakukan (Berger \& Ofek, 1995; Lang \&Lundholm, 1996; Servaes 1996), bahwa diversifikasi perusahaan tidak dapat meningkatkan nilai perusahaan. Temuan tersebut diperkuat dengan studi yang dilakukan Lins \& Servaes, (2004), bahwa strategi diversifikasi yang diterapkan perusahaan di negara maju hanya menimbulkan biaya yang lebih besar daripada manfaat yang akan diperoleh. Sedangkan strategi diversifikasi bisnis perusahaan di negara berkembang memberikan manfaat yang lebih besar dibanding perusahaan yang fokus (hanya memiliki satu bisnis), hal ini karena adanya ketidaksempurnaan pasar modal. Sejalan dengan studi yang dilakukan (Khanna \& Palepu, 1997; 2000), bahwa strategi diversifikasi di negara berkembang lebih tepat dilakukan daripada fokus karena adanya perbedaan konteks institusional.

Selain itu, perusahaan melalui diversifikasi bisnis juga dapat memberikan kemudahan alokasi modal kerja, baik antar divisi dalam satu perusahaan maupun antar perusahaan dalam satu korporasi daripada sumber modal kerja di luar korporasi. Begitu juga hasil studi yang dilakukan Boot \& Schmeits (2000), menyatakan bahwa diversifikasi bisnis perusahaan dapat menurunkan biaya financial distress atau kebangkrutan dikarenakan adanya sebaran resiko pada produk bisnis yang berbeda. Sejalan dengan studi Templeton \& Severiens (1992) yang melakukan analisis terhadap kinerja pada 54 bank periode 1979-1986, hasil studi menunjukkan bahwa manfaat diversifikasi bisnis dapat menurunkan volatilitas keuntungan pemilik.

Diskusi studi terdahulu mengenai strategi diversifikasi bisnis perusahaan menunjukkan adanya manfaat dan kelemahan yang ditimbulkan bagi pemilik. Akan tetapi, terdapat banyak manfaat yang diperoleh apabila perusahaan menerapkan tata kelola perusahaan dengan baik. Perusahaan di negara berkembang, salah satunya Indonesia memiliki ciri kepemilikan terkonsentrasi sehingga memiliki hak suara dan kewenangan yang besar untuk mengawasi kebijakan manajer dan terciptanya tata kelola perusahaan yang baik. Selain itu peraturan pemerintah juga turut mendukung terciptanya tata kelola perusahaan yang baik, salah satunya memuat asas transparansi. Oleh karena itu, karakteristik kepemilikan terkonsentrasi dan adanya asas transparansi turut mendukung terciptanya tata kelola perusahaan yang baik, dengan demikian maka strategi diversifikasi mampu memberikan manfaat yang besar dan menurunkan konflik keagenan. Sehingga hipotesis terkait diversifikasi bisnis dan biaya modal ekuitas dapat dirumuskan: 
Pengaruh luas pengungkapan informasi, konsentrasi kepemilikan dan diversifikasi pada biaya modal ekuitas: studi pada perusahaan non-keuangan di indonesia

$\mathrm{H}_{3}$ : Diversifikasi bisnis berpengaruh positif pada biaya modal ekuitas.

\section{Metode Penelitian}

\section{Data dan Sampel}

Sampel dalam penelitian ini menggunakan perusahaan non-keuangan yang terdaftar didalam Bursa Efek Indonesia (BEI) periode 2010-2014. Perusahaan yang termasuk dalam sector keuangan dikeluarkan dalam penelitian, dikarenakan sektor keuangan termasuk dalam kategori highly regulated, sehingga memiliki karakteristik yang berbeda dengan perusahaan non keuangan, khususnya pada pendanaan (Nahda \& Asri, 2017). Data yang digunakan bersifat panel, diperoleh melalui website BEI, Yahoo finance, OSIRIS, dan laporan keungan perusahaan. Metode pengambilan sampel menggunakan teknik purposive sampling dengan kriteria sebagai berikut: a) perusahaan yang terdaftar di BEI dan tidak mengalami delisting selama periode 2010 sampai 2014 dan telah menerbitkan serta mempublikasikan laporan keuangan auditan untuk tahun buku yang berakhir pada tanggal 31 Desember. b) Perusahaan tidak bergerak di industri keuangan dan tidak memiliki unit bisnis yang bergerak dibidang tersebut. c) Perusahaan memiliki lebih dari dua segmen usaha dan perusahaan tersebut mengungkapkan informasi terkait dengan segmen usaha di dalam laporan tahunan. d) Adanya kontinuitas usaha segmen yang dilaporkan minimal 3 tahun berturut-turut.

\section{Definisi Operasional dan Pengukuran Variabel}

\section{Luas pengungkapan}

Pada penelitian ini menganalisis pengungkapan yang bersifat wajib dan sukarela. Daftar item pengungkapan wajib disusun berdasar kriteria penilaian Annual Report Award Bapepam-LK, dan dilengkapi dengan item-item pengungkapan sukarela berdasar penelitian Lim et al (2007) dan Jones (2007) (lihat Lampiran 1). Prosedur penetapan skor 1 jika item diungkapkan dan skor 0 jika informasi tidak diungkapkan. Pembobotan untuk masing-masing item pengukuran berbeda, tergantung dengan item rincian pengukuran (lihat Lampiran). Pengukuran luas pengungkapan mengacu penelitian yang dilakukuan oleh Pinasti (2012). Penelitian ini berbeda dengan penelitian yang dilakukan oleh Pinasti (2012), karena pada penelitian ini menganalisis luas pengungkapan terhadap biaya modal ekuitas, sedangkan penelitian Pinasti (2012) menganalisis luas pengungkapan terhadap laba perusahaan.

\section{Struktur kepemilikan}

Variabel struktur kepemilikan dihitung berdasarkan lima pemilik saham terbesar dengan prosentase kepemilikan sekurangnya 5\%. Seperti yang diatur dalam Undang-Undang Pasar Modal N0.8 Tahun 1995, Pasal 87 (2) mengatakan bahwa "Setiap Pihak yang memiliki sekurang-kurangnya 5\% (lima perseratus) saham Emiten atau Perusahaan Publik wajib melaporkan kepada Bapepam atas kepemilikan dan setiap perubahan kepemilikannya atas saham perusahaan tersebut".

\section{Diversifikasi bisnis}

Strategi diversifikasi dalam penelitian ini diukur dengan menggunakan 2 cara, yaitu dengan menghitung jumlah segmen bisnis dalam suatu perusahaan dan menggunakan indeks Herfindahl (Berger \& Ofek, 1995; Denis et. al., 1997; Franco et. al., 2010; Nahda \& Asri, 2017; Mansi \& Reeb, 2002). Indeks Herfindahl dihitung berdasarkan jumlah kuadrat penjualan masing-masing segmen dibagi dengan kuadrat total penjualan perusahaan. Semakin rendah HI maka semakin tinggi derajat diversifikasi. (Persamaan 1)

$\mathrm{HI}=\sum_{n=1}^{N}\left(\frac{\text { segsales }}{\text { totalsales }}\right)^{2}$ 


\section{Biaya modal ekuitas}

Biaya modal ekuitas merupakan biaya yang dikeluarkan untuk membiayai sumber pembelanjaan atau tingkat keuntungan yang disyaratkan oleh pemilik atas investasi (Brigham, 2011). Berdasar definisi tersebut, maka biaya ekuitas pada dasarnya merupakan cerminan biaya yang ditanggung perusahaan untuk kepentingan pemilik (Brigham, 2011).

Terdapat beberapa model yang sering digunakan untuk mengestimasi biaya modal ekuitas, diantaranya adalah: Constant growth valuation model (Brigham, 2011), CAPM (Jones, 2007) serta metode Ohlson (Botosan, 1997). Dari ketiga pendekatan tersebut penelitian ini menggunakan model CAPM. Hal ini dikarenakan penggunaan model CAPM memungkinkan untuk mengukur risiko, dengan melihat nilai beta pada masing-masing sekuritas. Selain itu menurut Weston \& Eugene (1986), pendekatan ini dapat memberikan hasil yang akurat dibandingkan pendekatan yang lain. Melalui pendekatan ini dapat diketahui berapa harga yang seharusnya dibayar oleh perusahaan terhadap modal tersebut. Periode pengukuran menggunakan pendekatan CAPM antara tahun 2010-2014. Penelitian ini menggunakan BI rate sebagai bebas resiko (rf) dalam menghitung nilai Beta.

Persamaan I: Menentukan nilai Beta

$R_{i}=\alpha_{i}+\beta_{i} R_{m}+e_{i}$

Dalam hal ini:

$\mathrm{R}_{\mathrm{i}} \quad=$ Return sekuritas

$\mathrm{R}_{\mathrm{m}}=$ Return indeks pasar (sektor manufaktur)

$\alpha_{i} \quad=$ Intersep

$\beta_{\mathrm{i}}=$ Slope

$\mathrm{e}_{\mathrm{i}} \quad=$ Random residual error

Persamaan II: Biaya Modal Ekuitas

$\mathrm{COE}=\mathrm{R}_{\mathrm{f}}+\beta_{\mathrm{i}} \mathrm{R}_{\mathrm{P}}$

Dalam hal ini:

$\mathrm{COE}=$ Estimasi biaya modal ekuitas

$\mathrm{R}_{\mathrm{f}}=$ risk free rate yang diproksi dengan treasury bond jangka panjang (lebih dari 10 tahun untuk masing-masing tahun pengamatan)

$\beta_{\mathrm{i}} \quad=$ Beta pasar dari standar deviasi return pasar (IHSG)

$\mathrm{R}_{\mathrm{P}}=$ Market risk premium $\left(\mathrm{R}_{\mathrm{m}}-\mathrm{R}_{\mathrm{f}}\right)$ yang diartikan sebagai return tambahan.

\section{Variabel kontrol}

Penelitian ini menggunakan empat karakteristik perusahaan sebagai variabel control yaitu leverage, kinerja perusahaan, ukuran perusahaan, dan likuiditas.

\section{Leverage}

Rasio leverage mengukur sejauh mana perusahaan menggunakan pendanaan melalui utang (Brigham, 2011). Penelitian ini menggunakan variabel kontrol leverage mengacu pada penelitian Hann et. al., (2013).

$$
\text { leverage }=\frac{\text { Nilai buku utang jangka panjang }}{\text { Nilai buku utang jangka panjang }+ \text { Nilai pasar ekuitas }}
$$

\section{Kinerja Perusahaan}

Franco et al., (2010) mengontrol pengaruh diversifikasi terhadap biaya modal ekuitas dengan kinerja perusahaan yang diukur dengan menggunakan return on assets (ROA) untuk mengontrol kemampuan perusahaan dalam menghasilkan laba. 
Pengaruh luas pengungkapan informasi, konsentrasi kepemilikan dan diversifikasi pada biaya modal ekuitas: studi pada perusahaan non-keuangan di indonesia

\section{Ukuran Perusahaan}

Penelitian ini memasukkan ukuran perusahaan sebagai variabel kontrol mengacu pada penelitian Hann et al., (2010) yang diukur dengan menggunakan logarithm natural dari total aset.

\section{Likuiditas}

Variabel likuiditas sebagai variabel control mengacu pada penelitian yang dilakukan Bodie et al., (2011) yang diukur dengan Curent asset: Curent Liabilities.

\section{Teknik Analisis Data}

Studi ini menggunakan model analisis regresi berganda untuk mengetahui pengaruh variabel luas pengungkapan, kepemilikan terkonsentrasi dan diversifikasi bisnis terhadap biaya modal ekuitas, sebagai berikut:

$$
\mathrm{BME}=\mathrm{a}-\mathrm{b}_{1} \mathrm{LUP}-\mathrm{b}_{2} \mathrm{SUK}+\mathrm{b}_{3} \mathrm{DIV}+\mathrm{b}_{4} \mathrm{UKU}+\mathrm{b}_{5} \mathrm{HUT}-\mathrm{b}_{6} \mathrm{KEU}-\mathrm{b}_{7} \mathrm{LIK}+\varepsilon
$$

Dalam hal ini:

$\mathrm{BME}=$ Biaya modal ekuitas; LUP $=$ Luas Pengungkapan; SUK= Konsentrasi Kepemilikan; DIV = Diversifikasi; UKU= Ukuran Perusahaan; HUT= Hutang; KEU= Profitabilitas; LIK= Liquiditas; $a=$ Konstanta; $b=$ Koefisien regresi; $\varepsilon=$ Residual error luas pengungkapan.

\section{Hasil Penelitian dan Pembahasan}

\section{Statistik Deskriptif}

Penelitian ini menggunakan sampel seluruh perusahaan non keuangan yang terdaftar di Bursa Efek Indonesia periode 2010-2014. Berdasarkan kriteria pemilihan sampel maka diperoleh sampel sebanyak 130 perusahaan selama periode pengamatan. Kemudian dari 130 perusahaan tersebut yang memenuhi kriteria diversifikasi adalah sebanyak 31 perusahaan. Sehingga total observasi menjadi 155 perusahaan.

Tabel 1. Statistik Deskriptif

\begin{tabular}{lccccc}
\hline \multicolumn{1}{c}{ Variabel } & Obs & Mean & Min & Max & SD \\
\hline BME (\%) & 155 & 17,45 & 2,23 & 56,50 & 12,63 \\
LUP (\%) & 155 & 67,04 & 43,46 & 92,94 & 10,12 \\
SUK (\%) & 155 & 67.92 & 25.00 & 98.85 & 17,84 \\
DIV (\%) & 155 & 56,73 & 26,16 & 99,66 & 21,84 \\
DIVS (\%) & 155 & 4,00 & 3.00 & 8.00 & 1,17 \\
UKU (\%) & 155 & 28,73 & 24,37 & 32,40 & 1,72 \\
HUT (\%) & 155 & 27,74 & 24,35 & 32,16 & 1,81 \\
LIK (\%) & 155 & 2,61 & 0,64 & 9,34 & 1,76 \\
KEU (\%) & 155 & 8,53 & 5,82 & 39,56 & 7,50 \\
\hline
\end{tabular}

Sumber: Hasil olah data

Berdasarkan hasil statistik deskriptif yang disajikan pada tabel 1 dapat dijelaskan bahwa dari 155 pengamatan secara rata-rata biaya modal ekuitas perusahaan adalah $17,45 \%$. Jika dilihat dari selisih antara biaya modal ekuitas terendah dengan biaya modal ekuitas tertinggi, maka terdapat perbedaan yang cukup tinggi yang menunjukkan bahwa tingkat variasi biaya modal ekuitas yang dikeluarkan perusahaan masih cukup tinggi.

Variabel luas pengungkapan laporan keuangan perusahaan pada 155 sampel pengamatan menunjukkan nilai minimum 43,46\% dan nilai maksimum mencapai 92,94\%, hal ini mengindikasikan bahwa perusahaan di Indonesia semakin transparan terhadap informasi yang dimiliki baik bersifat sukarela maupun wajib. Secara keseluruhan sampel, nilai rata-rata cukup tinggi yaitu sebesar 67,04\% 
( $>50 \%)$ dengan standar deviasi 0,1012 yang artinya penyebaran data cenderung homogen karena nilai standar deviasi hampir mendekati nol.

Struktur kepemilikan perusahaan di Indonesia tergolong terkonsentrasi, hal ini selaras dengan hasil statistik deskriptif yang menunjukkan bahwa secara rata-rata sebesar $67,92 \%(>50 \%)$, terendah sebesar $25 \%$ dan tertinggi yaitu $98,85 \%$. Nilai rata-rata variabel diversifikasi diukur dengan indeks herfindahl adalah sebesar $56,73 \%$ artinya perusahaan di Indonesia cenderung terdiversifikasi meskipun tergolong rendah karena nilai rata-rata di atas $50 \%$.

\section{Hasil Pengujian Hipotesis}

Tabel ini menyajikan hasil regresi berganda pada tiap variabel independen. Variabel dependen adalah biaya modal ekuitas. Variabel Independen terdiri dari Luas pengungkapan, Konsentrasi kepemilikan, Diversifikasi. Variabel control menggunakan Ukuran perusahaan, Hutang perusahaan, Likuiditas dan Profitabilitas perusahaan.

Tabel 2. Hasil Regresi Berganda

\begin{tabular}{|c|c|c|c|c|}
\hline Variabel Independen & Model 1 & Model 2 & Model 3 & Model 4 \\
\hline Luas Pengungkapan & $\begin{array}{l}-0,017 * * * \\
(0.002)\end{array}$ & $\begin{array}{l}-0,002 * * \\
(0.001)\end{array}$ & & \\
\hline Luas Pengungkapan_Wajib & & & $\begin{array}{l}-0,003^{* * *} \\
(0.001)\end{array}$ & \\
\hline Luas Pengungkapan_Sukarela & & & & $\begin{array}{l}-0,002^{*} \\
(0.001)\end{array}$ \\
\hline Konsentrasi Kepemilikan_KONS & $\begin{array}{l}-0,003 * * \\
(0.001)\end{array}$ & & $\begin{array}{l}-0,471 * * \\
(0.186)\end{array}$ & $\begin{array}{l}-0,628 * * * \\
(0.157)\end{array}$ \\
\hline Konsentrasi Kepemilikan_HI & & $\begin{array}{l}-1,033 * * * \\
(0,166)\end{array}$ & & \\
\hline Diversifikasi Bisnis_HI & $\begin{array}{l}-0,045^{* * *} \\
(0.017)\end{array}$ & & $\begin{array}{l}-0,727 * * * \\
(0.155)\end{array}$ & $\begin{array}{l}-0,393 * * * \\
(0.136)\end{array}$ \\
\hline Diversifikasi Bisnis_Segmen Bisnis & & $\begin{array}{l}-0,028 * * \\
(0.015)\end{array}$ & & \\
\hline Ukuran Perusahaan & $\begin{array}{l}0,065^{* * *} \\
(0.015)\end{array}$ & $0,007(0.022)$ & $\begin{array}{l}0,000 * * * \\
(0.024)\end{array}$ & $\begin{array}{l}-0,018 \\
(0.024)\end{array}$ \\
\hline Hutang Perusahaan & $\begin{array}{l}0,004 * \\
(0.002)\end{array}$ & $0,015(0.022)$ & $\begin{array}{l}0,015 \\
(0.024)\end{array}$ & $\begin{array}{l}0,027 \\
(0.024)\end{array}$ \\
\hline Likuiditas Perusahaan & $\begin{array}{l}-0,001 \\
(0.003)\end{array}$ & $0,007(0.007)$ & $\begin{array}{l}-0,006 \\
(0.008)\end{array}$ & $\begin{array}{l}0,001 \\
(0.008)\end{array}$ \\
\hline Profitabiltas Perusahaan & $\begin{array}{l}-0,129 * * \\
(0.063) \\
\end{array}$ & $0,197(0.145)$ & $\begin{array}{l}0,199 \\
(0.154)\end{array}$ & $\begin{array}{l}-0,018 \\
(0.024) \\
\end{array}$ \\
\hline
\end{tabular}

Sumber: Data diolah 2016

Cat: $\mathrm{N}=155 ; \mathrm{R}^{2}=0,890 ;{ }^{*} \mathrm{p}<0.10,{ }^{* *} \mathrm{p}<0.05,{ }^{* *} \mathrm{p}<0.01$, Standard error terdapat di dalam tanda kurung

\section{Analisis Hasil dan Pembahasan}

\section{Luas Pengungkapan dan Biaya Modal Ekuitas}

Hipotesis penelitian pertama menyatakan bahwa luas pengungkapan berpengaruh negatif terhadap biaya modal ekuitas. Pengujian hipotesis ini menggunakan analisis regresi berganda, hasil pengujian ditunjukkan pada tabel 2. Berdasar tabel 2 pada model 1 dan model 2 keduanya menunjukkan luas pengungkapan mempunyai pengaruh signifikan dengan $\alpha 1 \%$ arah negatif. Pengujian lebih lanjut dilakukan pada model 3 dan model 4 , untuk mengetahui pengaruh masing-masing pengungkapan yang bersifat wajib dan sukarela. Hasil statistic menunjukkan bahwa luas pengungkapan wajib maupun sukarela berpengaruh signifikan dengan arah negative. Sehingga hipotesis pertama didukung 
Pengaruh luas pengungkapan informasi, konsentrasi kepemilikan dan diversifikasi pada biaya modal ekuitas: studi pada perusahaan non-keuangan di indonesia

secara statistik. Temuan ini mengindikasikan bahwa semakin luas pengungkapan informasi perusahaan baik yang bersifat wajib maupun sukarela maka biaya modal ekuitas secara rata-rata semakin rendah. Hasil penelitian ini sejalan dengan penelitian terdahulu (Botosan, 1997; Chen et al., 2004; Gulo, 2000; Khomsiyah, 2003: Kristandl \& Bontis, 2007; Mardiyah, 2002).

Luas pengungkapan informasi perusahaan dapat menurunkan biaya modal ekuitas, hal ini dapat dijelaskan melalui dua pandangan. Pertama, pengungkapan dapat menurunkan biaya modal ekuitas karena semakin berkurangnya infomasi asimetri, sehingga perdagangan di pasar modal semakin likuid (Diamond \& Verrecchia 1991; Healy \& Palepu 2001; Welker 1995). Kedua, luas pengungkapan informasi yang dilakukan perusahaan dapat menurunkan resiko, dikarenakan investor memiliki kepastian dan keyakinan terhadap masa depan perusahaan. Temuan tersebut sejalan dengan Khomsiyah (2003), Kristandl \& Bontis (2007) dan Mardiyah (2002), yang menyatakan bahwa luas pengungkapan dapat menurunkan: ketidakpastian, konflik informasi asimetri dan keagenan, resiko yang ditanggung investor, dan meningkatkan: keyakinan dan kepastian investor terhadap perusahaan, keinginan untuk melakukan investasi kembali. Luas pengungkapan juga memiliki peran yang besar dalam mengatasi masalah informasi asimetri dan keagenan (Healy \& Palepu, 2001).

Kedua pengungkapan informasi wajib dan sukarela memiliki manfaat yang besar bagi perusahaan-perusahaan di negara berkembang (Asia) yaitu, mampu menurunkan: volatilitas, insider trading, dan biaya modal ekuitas (Andriessen, 2004; Botosan, 1997; Leadbetter, 2000; Roos et al., 2004). Hasil studi tersebut berdasarkan teori pendekatan likuiditas, yaitu semakin rendah informasi asimetri maka dapat meningkatkan likuiditas pasar (Baiman \& Verrecchia, 1995), dan pendekatan estimasi resiko yaitu peningkatan pengungkapan informasi perusahaan mampu menurunkan estimasi resiko sehingga keuntungan yang disyaratkan pemilik menjadi berkurang, karena resiko berbanding lurus dengan keuntungan yang disyaratkan pemilik (Coles \& Loewenstein, 1988).

\section{Struktur Kepemilikan dan Biaya Modal Ekuitas}

Perusahaan di Indonesia khususnya yang bergerak dibidang manufaktur seperti yang telah dijelaskan sebelumnya memiliki karakteristik struktur kepemilikan terkonsentrasi atau memusat. Seperti yang dijelaskan Claessens et al. (2000) bahwa sebagaimana negara-negara di Asia Timur dan Asia Tenggara emiten di pasar modal Indonesia memiliki struktur kepemilikan yang cenderung terkonsentrasi pada satu atau sedikit pemegang saham berbeda dengan kepemilikan pada negara maju lainnya yang cenderung menyebar.

Hipotesis kedua penelitian ini menyatakan bahwa struktur kepemilikan berpengaruh negatif terhadap biaya modal ekuitas. Hasil empiris pada tabel 2 model 1,2,3,4 menunjukkan bahwa struktur kepemilikan signifikan negatif terhadap biaya modal ekuitas, diukur menggunakan konsentrasi kepemilikan maupun Indeks Herfindahl. Sehingga hipotesis kedua terdukung secara statistik. Temuan ini sejalan dengan temuan yang dilakukan oleh Brickley, Lease \& Smith, (1988), Denis et al., (1999), Demsetz \& Lehn (1985), La Porta et al., (1999), dan Shleifer \& Vishny (1997).

Struktur kepemilikan dapat dijelaskan melalui teori keagenan, Jensen \& Meckling (1976) menyatakan teori agensi adalah hubungan keagenan dalam bentuk sebuah kontrak, teori agensi menurut Eisendhart (1989) menggunakan tiga asumsi sifat manusia, salah satunya adalah manusia mementingkan diri sendiri. Sifat manusia yang cenderung mementingkan diri sendiri serta adanya asimetri informasi antara pengelola dan pemilik, maka besar kemungkinan akan terjadi konflik, karena manajemen bertindak tidak sesuai dengan kepentingan pemilik.

Oleh karena itu, dengan tipe kepemilikan terkonsentrasi maka menurut Shleifer \& Vishny (1997) pemilik besar dapat melakukan pengawasan karena mendapatkan informasi dan memonitor manajemen serta mempunyai hak suara untuk menekan manajemen dalam berbagai kasus. Hal ini dilakukan dengan tujuan untuk mengurangi perilaku oportunistik dari manajer perusahaan sehingga dapat mengurangi biaya ekuitas menjadi lebih rendah. Sejalan dengan Demsetz \& Lehn (1985) menjelaskan bahwa konsentrasi kepemilikan menghilangkan konflik kepentingan antara pemilik dan manajer karena pemilik memiliki hak besar untuk mengawasi manajer. 


\section{Diversifikasi Bisnis dan Biaya Modal Ekuitas}

Hipotesis ketiga penelitian ini berkaitan pula dengan isu tata kelola perusahaan yaitu mengenai diversifikasi, karena strategi diversifikasi yang dilakukan tidak selalu selaras dengan kepentingan pemilik, misalnya tidak selalu menurunkan biaya modal ekuitas (Mardiah, 2002). Hasil uji secara statistik menunjukkan diversifikasi diukur dengan menggunakan indeks herfindahl signifikan negative, hasil yang sama saat diukur dengan menggunakan jumlah segmen. Sehingga hipotesis ketiga dalam penelitian ini tidak terdukung secara statistic. Temuan ini mengindikasikan bahwa semakin terdiversifikasi suatu perusahaan maka biaya modal ekuitas justru semakin meningkat. Perbedaan arah tersebut dijelaskan berdasar teori coinsurance, konflik keagenan dan pendanaan internal.

Alasan pertama berdasar pada teori coinsurance bahwa variabilitas arus kas dapat menurunkan risiko perusahaan melalui diversifikasi. Dengan penurunan risiko kesempatan perusahaan untuk meningkatkan kapasitas utang meningkat. Disisi lain, risiko terjadi kebangkrutan menjadi bertambah. Sehingga perusahaan semakin berisiko berdampak pada biaya modal ekuitas yang meningkat. Secara empiris, hasil regresi didukung oleh Galai \& Masulis (1976) dan Mansi \& Reeb (2002).

Alasan kedua dapat dijelaskan berdasar teori keagenan dan pasar pendanaan internal seperti yang diungkapkan oleh Berger \& Ofek (1995), Amihud \& Lev (1999), dan Mansi \& Reeb (2002). Pada saat terjadi konflik kepentingan dapat mempengaruhi keputusan transfer sumber daya menjadi kurang efisien, maka diversifikasi justru akan meningkatkan risiko perusahaan (Berger \& Ofek, 1995).

\section{Simpulan dan Saran Pengembangan}

Berdasarkan hasil penelitian menunjukkan bahwa luas pengungkapan yang dilakukan perusahaan dapat mengurangi biaya modal ekuitas yang disyaratkan oleh pemilik terhadap perusahaan atas dana investasi pada perusahaan tersebut. Penelitian ini menunjukkan bahwa semakin terkonsentrasi kepemilikan maka justru semakin berkurang biaya modal ekuitas yang dibebankan pemilik terhadap perusahaan. Sedangkan strategi diversifikasi yang dilakukan oleh perusahaan justru dapat meningkatkan biaya modal ekuitas, hal ini dikarenakan diversifikasi yang dilakukan perusahaan justru meningkatkan biaya akibat inefisiensi dalam pengalokasian dana (Mackey \& Barney, 2006).

Adapun keterbatasan dari penelitian ini yang juga menjadi saran untuk penelitian selanjutnya adalah sebagai berikut:

a. Model penelitian ini dibangun berdasar penerapan tata kelola yang baik terhadap biaya modal ekuitas, sedangkan struktur modal perusahaan terdiri dari modal dan hutang. Penelitian ini hanya menghitung biaya modal ekuitas belum mempertimbangkan dampak konflik keagenan terhadap biaya hutang. Penelitian selanjutnya diharapkan menghitung struktur modal secara kesuluruhan yang terdiri dari modal dan hutang.

b. Penelitian ini menguji secara langsung pengaruh dari luas pengungkapan, struktur kepemilikan, dan diversifikasi bisnis terhadap biaya modal ekuitas belum memperhitungkan asimetri informasi, asimetri informasi hanya menjadi isu penelitian saja sehingga belum diketahui pengaruh secara tidak langsung antara luas pengungkapan terhadap biaya modal ekuitas. Penelitian selanjutnya diharapkan menghitung nilai asimetri informasi sebagai variabel moderasi antara luas pengungkapan terhadap biaya modal ekuitas.

c. Struktur kepemilikan dalam penelitian ini hanya dihitung secara keseluruhan dengan melihat prosentase ukuran terkonsentrasi, belum menghitung keberadaan kepemilikan institusional dalam perusahaan. Penelitian selanjutnya juga diharapkan mempertimbangkan keberadaan kepemilikan institusional dalam perusahaan karena bisa jadi akan mendapatkan temuan yang berbeda.

d. Fokus sampel penelitian hanya pada perusahaan terdiversifikasi bisnis saja, sehingga tidak bisa didapat besaran manfaat perusahaan terdiversifikasi dibanding dengan tidak terdiversifikasi 
dalam konteks biaya modal ekuitas. Penelitian selanjutnya diharapkan juga menghitung biaya modal ekuitas pada perusahaan yang tidak terdiversifikasi.

e. Biaya modal ekuitas dihitung menggunakan CAPM, dalam perhitungan CAPM risk free menggunakan data dari BI rate. Terdapat kelemahan apabila menggunakan data BI rate, yaitu sebaran data cukup fluktuatif, sehingga untuk penelitian selanjutnya diharapkan menggunakan proksi yang lebih stabil dalam menghitung risk free.

\section{Daftar Pustaka}

Aggarwal, R. K., \& Samwick, A. A. (2003). Why do managers diversify their firms? Agency reconsidered. The Journal of Finance, 58(1), 71-118.

Akhtaruddin, M., Hossain, M. A., Hossain, M., \& Yao, L. (2009). Corporate governance and voluntary disclosure in corporate annual reports of Malaysian listed firms. Journal of Applied Management Accounting Research, 7(1), 1.

Alesón, M. R., \& Escuer, M. E. (2002). The impact of product diversification strategy on the corporate performance of large Spanish firms. Spanish Economic Review, 4(2), 119-137.

Amihud, Y. \& B. Lev. (1981). Risk Reductions as a Managerial Motive for Conglomerate Mergers. Bell Journal of Economics.

Amihud, Y., \& Lev, B. (1981). Risk reduction as a managerial motive for conglomerate mergers. The bell journal of economics, 605-617.

Anderson, R. C., Bates, T. W., Bizjak, J. M., \& Lemmon, M. L. (2000). Corporate governance and firm diversification. Financial management, 5-22.

Anggraini, F. R. R. (2006). Pengungkapan informasi sosial dan faktor-faktor yang mempengaruhi pengungkapan informasi sosial dalam laporan keuangan tahunan (Studi empiris pada perusahaan-perusahaan yang terdaftar Bursa Efek Jakarta). Simposium Nasional Akuntansi, 9, 23-26.

Ashbaugh, H., D.W. Collins, \& R. LaFond, (2004). Corporate Governance and the Cost of Equity Capital. http://papers.ssrn.com/so13/papers.cfm?abstract id=639681

Baiman, S., \& Verrecchia, R. E. (1995). Earnings and price-based compensation contracts in the presence of discretionary trading and incomplete contracting. Journal of Accounting and Economics, 20(1), 93-121.

Barry, C. \& Brown, S. (1985). Differential information and security market equilibrium. Journal of Financial and Quantitative Analysis

Berger, P. G., \& Ofek, E. (1995). Diversification's effect on firm value. Journal of financial economics, 37(1), 39-65.

Berton, L. (1994). Companies pressure accounting panel to modify demands for more data. Wall Street Journa, 16, A2.

Bhagat, S., \& Bolton, B. (2008). Corporate governance and firm performance. Journal of corporate finance, 14(3), 257-273.

Bloomfield, R. J., \& Wilks, T. J. (2000). Disclosure effects in the laboratory: Liquidity, depth, and the cost of capital. The Accounting Review, 75(1), 13-41.

Boot, A. W., \& Schmeits, A. (2000). Market discipline and incentive problems in conglomerate firms with applications to banking. Journal of financial intermediation, 9(3), 240-273.Botosan,

Botosan, C. A. (1997). Disclosure level and the cost of equity capital. Accounting review, 323-349. 
Botosan, C. A., \& Plumlee, M. (2000). Disclosure level and expected cost of equity capital: An examination of analysts' rankings of corporate disclosure and alternative methods of estimating expected cost of equity capital.

Brickley, J. A., Lease, R. C., \& Smith Jr, C. W. (1988). Ownership structure and voting on antitakeover amendments. Journal of financial economics, 20, 267-291.Brigham, E. 2011. Intermediate Financial Management (7th ed). United States: South Western Thompson Learning.

Chen, K. C., Wei, K. C., \& Chen, Z. (2003). Disclosure, corporate governance, and the cost of equity capital: evidence from Asia's emerging markets.

Chen, S. S., \& Ho, K. W. (2000). Corporate diversification, ownership structure, and firm value: The Singapore evidence. International Review of Financial Analysis, 9(3), 315-326.

Claessens, S., Djankov, S., Fan, J. P., \& Lang, L. H. (1999). Corporate diversification in East Asia: The role of ultimate ownership and group affiliation (No. 2089). The World Bank.

Coles, J. L., \& Loewenstein, U. (1988). Equilibrium pricing and portfolio composition in the presence of uncertain parameters. Journal of Financial Economics, 22(2), 279-303.

Collins, D., \& Huang, H. (2011). Management entrenchment and the cost of equity capital. Journal of Business Research,64(4), 356-362.Demsetz, H. and Lehn, K. 1985. The Structure of Corporate Ownership: Causes and Consequences. The Journal of Political Economy.

Denis, D. J., Denis, D. K., \& Yost, K. (2002). Global diversification, industrial diversification, and firm value. The journal of Finance, 57(5), 1951-1979.

Dharmadasa, P., Gamage, P., \& Herath, S. K. (2014). Corporate governance, board characteristics and firm performance: evidence from Sri Lanka. South Asian Journal of Management, 21(1), 7.

Diamond, D. W., \& Verrecchia, R. E. (1991). Disclosure, liquidity, and the cost of capital. The journal of Finance, 46(4), 1325-1359.

Dowling, J., \& Pfeffer, J. (1975). Organizational legitimacy: Social values and organizational behavior. Pacific sociological review, 18(1), 122-136.

Eisendhart, K. (1989). Agency Theory: An Assessment and Review. Academy of Management Review.

Elyasiani, Elyas and Wang, Yong. (2009). Diversification and Firm's Cost of Capital. http://WWW.researchgate.net/publication/265223467.

Galai, D., \& Masulis, R. W. (1976). The option pricing model and the risk factor of stock. Journal of Financial economics, 3(1-2), 53-81.

Wati, L. M. (2013). Pengaruh praktek good corporate governance terhadap kinerja Keuangan perusahaan di Bursa Efek Indonesia. Jurnal Manajemen, 1(01).

Hann, R. N., Ogneva, M., \& Ozbas, O. (2013). Corporate diversification and the cost of capital. The journal of finance, 68(5), 1961-1999.

Healy, P. M., \& Palepu, K. G. (2001). Information asymmetry, corporate disclosure, and the capital markets: A review of the empirical disclosure literature. Journal of accounting and economics, 31(1-3), 405-440.

Hill, C. W., Jones, G. R., \& Schilling, M. A. (2014). Strategic management: theory: an integrated approach. Cengage Learning.

Jensen, M. C., \& Meckling, W. H. (1976). Theory of the firm: Managerial behavior, agency costs and ownership structure. Journal of financial economics, 3(4), 305-360. 
Pengaruh luas pengungkapan informasi, konsentrasi kepemilikan dan diversifikasi pada biaya modal ekuitas: studi pada perusahaan non-keuangan di indonesia

Jones, D. A. (2007). Voluntary disclosure in R\&D-intensive industries. Contemporary Accounting Research, 24(2), 489-522.

Khanna, T., \& Yafeh, Y. (2005). Business groups and risk sharing around the world. The Journal of Business, 78(1), 301-340.

Khomsiyah, (2003). Hubungan Corporate Governance dan Pengungkapan Informasi: Pengujian secara Simultan. Makalah Simposium Nasional Akuntansi ke V.

Kristandl, G., \& Bontis, N. (2007). Constructing a definition for intangibles using the resource-based view of the firm. Management decision, 45(9), 1510-1524.

Lakhal, F. (2003). Earning voluntary disclosures and corporate governance: Evidence from France.Lang, M. and R. Lundholm, 1996. Corporate Disclosure Policy and Analyst Behavior. Accounting Review.

La Porta, R., Lopez-de-Silanes, F., \& Shleifer, A. (1999). Corporate ownership around the world. The journal of finance, 54(2), 471-517.

Leadbetter, C. (2000). New Measures for the New Economy. Institute of Chartered Accountants in England and Wales, London.

Leuz, C., \& Verrecchia, R. E. (2000). The economic consequences of increased disclosure. Journal of accounting research, 91-124.

Lins, K. V., \& Servaes, H. (2002). Is corporate diversification beneficial in emerging markets? Financial Management, 5-31.

Mackey, T. B., \& Barney, J. B. (2006, August). Is There a Diversification Discount? Diversification, Payout Policy, and the Value of a Firm. In Academy of Management Proceedings (Vol. 2006, No. 1, pp. NN1-NN6). Briarcliff Manor, NY 10510: Academy of Management.

Mansi, S. A., \& Reeb, D. M. (2002). Corporate diversification: what gets discounted? The Journal of Finance, 57(5), 2167-2183.

Mardiyah, A. A. (2002). Pengaruh informasi asimetri dan disclosure terhadap cost of capital. The Indonesian Journal of Accounting Research, 5(2).

McConnell, J. J., \& Servaes, H. (1990). Additional evidence on equity ownership and corporate value. Journal of Financial economics, 27(2), 595-612.

Mishra, C. S., Randøy, T., \& Jenssen, J. I. (2001). The effect of founding family influence on firm value and corporate governance. Journal of International Financial Management \& Accounting, 12(3), 235-259.

Mitton, T. (2002). A cross-firm analysis of the impact of corporate governance on the East Asian financial crisis. Journal of financial economics, 64(2), 215-241.

Morck, R., Wolfenzon, D., \& Yeung, B. (2005). Corporate governance, economic entrenchment, and growth. Journal of economic literature, 43(3), 655-720.Nachum, L. 2004. Geographic and Industrial Diversification of Developing Country Firms. Journal of Management Studies.

Nuswandari, C. (2009). Pengaruh corporate governance perception index terhadap kinerja perusahaan pada perusahaan yang terdaftar di bursa efek Jakarta. Jurnal Bisnis dan Ekonomi, 16(2).

Palich, L. E., Cardinal, L. B., \& Miller, C. C. (2000). Curvilinearity in the diversification-performance linkage: an examination of over three decades of research. Strategic management journal, 21(2), 155-174. 
Patrisia, D. (2007). Diversifikasi dan Nilai Perusahaan dalam Perspektif Teori Keagenan. Tesis: Universitas Gadjah Mada. Yogyakarta.

Pinasti, M. (2012). Pengungkapan dan Kualitas Laba Terhadap Kegunaan Informasi Akuntansi bagi Investor: Suatu Usaha Penginteraksian Prospektif Informasi dan Perspektif Pengukuran. Disertasi: Universitas Gadjah Mada. Yogyakarta.

Pound, J. (1988). Proxy contests and the efficiency of shareholder oversight. Journal of financial economics, 20, 237-265.Rose, N. L., and Shepard, A. 1997. Firm diversification and CEO compensation: Managerial ability or executive entrenchment? The Rand Journal of Economics,

Rumelt, R. P. (1974). Strategy, structure, and economic performance. Sayidah, Nur. 2007. Pengaruh Kualitas Corporate Governance Terhadap Kinerja Perusahaan Publik. Jurnal Akuntansi dan Auditing Indonesia.

Schultze, W. (2004). Value-relevant disclosures (value reporting): conceptual framework and current practice of the German DAX100 firms. paper presented at the 27th Annual Congress of the European Accounting Association, Prague, April.

Servaes, H. (1996). The value of diversification during the conglomerate merger wave. The Journal of Finance, 51(4), 1201-1225.

Shin, H. H., \& Stulz, R. M. (1998). Are internal capital markets efficient? The Quarterly Journal of Economics, 113(2), 531-552.

Shleifer, A., \& Vishny, R. W. (1997). A survey of corporate governance. The journal of finance, 52(2), 737-783.

Sriwedari, T. (2012). Mekanisme Good Corporate Governance, Manajemen Laba dan Kinerja Keuangan Perusahaan Manufaktur di Bursa Efek Indonesia. Jurnal Mediasi, 4(01), 78-88.

Sukamulja, S. (2004). Good Corporate Governance di Sektor Keuangan: Dampak Good Corporate Governance Terhadap Kinerja Keuangan. Simposium Nasional Akuntansi VII Denpasar.

Tan, G. (2000). The Asian currency crisis.

Marshall Cavendish International.Templeton, W. K., \& Severiens, J. T. (1992). The effect of nonbank diversification on bank holding company risk. Quarterly Journal of Business and Economics, 3-17.

Tsai, W. H., Kuo, Y. C., \& Hung, J. H. (2009). Corporate diversification and CEO turnover in family businesses: self-entrenchment or risk reduction? Small Business Economics, 32(1), 57-76.

Wati, L. M. (2013). Pengaruh praktek good corporate governance terhadap kinerja Keuangan perusahaan di Bursa Efek Indonesia. Jurnal Manajemen, 1(01).

Watson, A., Shrives, P., \& Marston, C. (2002). Voluntary disclosure of accounting ratios in the UK. The British Accounting Review, 34(4), 289-313.

Welker, M. (1995). Disclosure policy, information asymmetry, and liquidity in equity markets. Contemporary accounting research, 11(2), 801-827.

Weston J. F \& Eugene F. B. (1986). Dasar-dasar Manajemen Keuangan Jilid I dan II. Terjemahan A.Q. Khalid. Penerbit Erlangga. Jakarta.

Wolk, H. I. et al. (2001). Accounting Theory: A Conceptual and Institutional Approach. Fifth edition, South-Western College Publishing. 
Pengaruh luas pengungkapan informasi, konsentrasi kepemilikan dan diversifikasi pada biaya modal ekuitas: studi pada perusahaan non-keuangan di indonesia

Young, M. N., Peng, M. W., Ahlstrom, D., Bruton, G. D., \& Jiang, Y. (2008). Corporate governance in emerging economies: A review of the principal-principal perspective. Journal of management studies, 45(1), 196-220.

Zhuang, J., Edwards, D., \& Capulong, M. V. A. (2001). Corporate Governance \& Finance in East Asia: A Study of Indonesia, Republic of Korea, Malaysia, Philippines and Thailand. Asian Development Bank. 


\section{Lampiran 1. Formulir Pengukuran Luas Pengungkapan}

\begin{tabular}{lllc}
\hline No. & Item-Item Informasi & Rincian & Nilai \\
\hline A & Umum & & $0-1$ \\
\hline 1 & penyajian dlm Bahasa Indonesia dan bahasa Inggris & & $0-2 / 2$ \\
2 & Mencantumkan identitas Perusahaan dg jelas & Nama Perusahaan dan Tahun Laporan Tahunan & \\
& & ditampilkan di: & 1. Sampul muka, samping, belakang \\
& & 2. Setiap halaman & $0-1$
\end{tabular}

\begin{tabular}{|c|c|c|c|}
\hline 3 & laporan Tahunan ditampilkan di website Perusahaan & & $0-1$ \\
\hline $\mathrm{B}$ & Ikhtisar Data Keuangan Penting & & $0-11 / 11$ \\
\hline 1 & $\begin{array}{l}\text { Info keuangan dlm bentuk perbandingan selama } 5 \text { th buku } \\
\text { atau sejak memulai usahanya (jika perusahaan tsb } \\
\text { menjalankan keg usahanya slm kurang dari } 5 \text { th) }\end{array}$ & $\begin{array}{l}\text { Informasi memuat: } \\
\text { 1. penjualan /pendapatan } \\
\text { 2. laba (rugi) kotor } \\
\text { 3. Laba (rugi) usaha } \\
\text { 4. Laba (rugi) bersih } \\
\text { 5. Laba (rugi) bersih per saham } \\
\text { 6. Modal kerja bersih } \\
\text { 7. Jumlah Investasi } \\
\text { 8. Jumlah Aktiva } \\
\text { 9. Jumlah Kewajiban } \\
\text { 10. Jumlah ekuitas } \\
\text { 11. Rasio Keuangan } \\
\end{array}$ & \\
\hline 2 & $\begin{array}{l}\text { Informasi harga saham tertinggi, terendah, penutupan dan } \\
\text { jumlah saham yang diperdagangkan }\end{array}$ & Dalam bentuk: (1) tabel; (2) grafik & $0-2 / 2$ \\
\hline 3 & tanda tangan anggota direksi dan anggota dewan komisaris & $\begin{array}{l}\text { 1. tanda tangan dituangkan pada lembaran } \\
\text { tersendiri } \\
\text { 2. Pernyataan bahwa direksi \& dewan } \\
\text { komisaris bertanggung jawab penuh atas } \\
\text { kebenaran isi lap tahunan } \\
\text { 3. Ditandatangan seluruh anggota dewan } \\
\text { komisaris \& direksi dg menyebut nama } \\
\text { \&jabatannya } \\
\text { 4. Penjelasan tertulis jika tdpt anggota dewan } \\
\text { komisaris/direksi yg tidak menandatangani } \\
\text { lap tahunan }\end{array}$ & $0-3 / 3$ \\
\hline $\mathrm{C}$ & Profil Perusahaan & & \\
\hline 1 & Nama dan alamat perusahaan & & $0-1$ \\
\hline 2 & Riwayat singkat perusahaan & $\begin{array}{l}\text { a.I.: tanggal/tahun pendirian, nama dan } \\
\text { perubahan nama perusahaan (jika ada) }\end{array}$ & $0-1$ \\
\hline 3 & Bidang usaha & $\begin{array}{l}\text { 1. Bidang Industri } \\
\text { 2. Jenis produk dan atau jasa yang dihasilkan } \\
\text { dalam bentuk bagan }\end{array}$ & $0-2 / 2$ \\
\hline 4 & Struktur organisasi & & $0-1$ \\
\hline 5 & Visi dan Misi perusahaan & $\begin{array}{ll}\text { 1. } & \text { Visi perusahaan } \\
\text { 2. } & \text { Misi perusahaan } \\
\text { 3. Penjelasan ttg visi perush } \\
\text { 4. } & \text { Penjelasan ttg misi perush } \\
\end{array}$ & $0-4 / 4$ \\
\hline 6 & $\begin{array}{l}\text { Nama, jabatan, dan riwayat hidup singkat anggota Dewan } \\
\text { Komisaris }\end{array}$ & $\begin{array}{l}\text { 1. Nama } \\
\text { 2. Jabatan } \\
\text { 3. Riwayat hidup singkat (umur, pendidikan, } \\
\text { pengalaman kerja) }\end{array}$ & $0-3 / 3$ \\
\hline 7 & Nama, jabatan, dan riwayat hidup singkat anggota Direksi & $\begin{array}{ll}\text { 1. Nama } \\
\text { 2. Jabatan } \\
\text { 3. Riwayat hidup singkat (umur, pendidikan, } \\
\text { pengalaman kerja) }\end{array}$ & $0-3 / 3$ \\
\hline 8 & komposisi pemegang saham & $\begin{array}{l}\text { 1. Nama pemegang saham yang memiliki } 5 \% \\
\text { atau lebih saham } \\
\text { 2. Direktur \& komisaris yg memiliki saham } \\
\text { 3. Pemegang shm masyarakat }\end{array}$ & $0-3 / 3$ \\
\hline 9 & $\begin{array}{l}\text { Daftar Anak Perusahaan dan atau Perusahaan Asosiasi (jika } \\
\text { dapat diterapkan) }\end{array}$ & $\begin{array}{l}\text { 1. Nama Anak Perusahaan/Perush Asosiasi } \\
\text { 2. Persentase kepemilikan saham } \\
\text { 3. Keterangan ttg bidang usaha } \\
\text { 4. Keterangan ttg status operasi }\end{array}$ & $0-4 / 4$ \\
\hline
\end{tabular}

$10 \quad$ Kronologis pencatatan saham

1. Kronologis pencacatan shm 
Pengaruh luas pengungkapan informasi, konsentrasi kepemilikan dan diversifikasi pada biaya modal ekuitas: studi pada perusahaan non-keuangan di indonesia

2. Jenis tindakan korporasi yg menyebabkan perusaan jml shm

3. Perubahan jml shm dari awal pencatatan s.d. akhir th buku

4. Nama bursa dimana saham perusahaan dicatatkan

11 Kronologis pencatatan Efek lainnya (jika dpt diterapkan)

1. Kronologis pencatatan Efek

2. Jenis tindakan korporasi yg menyebabkan perubahan jml Efek

3. Perubahan jml Efek dari awal pencatatan s.d. akhir th buku

4. Nama bursa dimana saham perusahaan dicatatkan

5. Peringkat Efek

12 Nama dan alamat lembaga dan atau profesi penunjang pasar modal

1. Nama dan alamat BAE

2. Nama dan alamat KAP

3. Nama dan alamat perusahaan pemeringkat efek

13 Akuntan Perseroan

1. Berapa periode audit KAP telah mengaudit lap keu perusahaan

2. besarnya fee audit

3. Jasa lain yg diberikan

14 Penghargaan \& sertifikasi yg diterima perush baik yg berskala nasional maupun internasional. (jika dapt diterapkan)

1. Nama Penghargaan

2. Tahun Perolehan

3. Badan pemberi penghargaan

4. Masa berlaku

\begin{tabular}{|c|c|c|c|}
\hline 15 & $\begin{array}{l}\text { Nama dan alamat anak perusahaan dan atau kantorcabang (jika } \\
\text { ada) }\end{array}$ & & $0-1$ \\
\hline $\mathrm{D}$ & Pembahasan Kinerja Perusahaan & & $0-4 / 4$ \\
\hline 1 & Tinjauan operasi per segmen usaha (jika dpt diterapkan) & $\begin{array}{ll}\text { 1. } & \text { Produksi } \\
\text { 2. Penjualan/ pendapatan usaha } \\
\text { 3. Profitabilitas } \\
\text { 4. Peningkatan/penurunan kapasitas produksi } \\
\text { u/ tiap segmen }\end{array}$ & \\
\hline 2 & $\begin{array}{l}\text { Uraian/analisis kinerja keuangan perbandingan antara kinerja } \\
\text { keuangan } \\
\text { th ybs dg th sebelumnya (dlm bentuk narasi dan/atau tabel) }\end{array}$ & $\begin{array}{l}\text { 1. Aktiva lancar, aktiva tidak lancar, dan } \\
\text { jumlah aktiva } \\
\text { 2. Kewajiban lancar, Keuangan tidak lancar } \\
\text { dan jumlah kewajiban } \\
\text { 3. Penjualan/pendapatan usaha } \\
\text { 4. Beban Usaha } \\
\text { 5. Laba/rugi bersih }\end{array}$ & $0-5 / 5$ \\
\hline 3 & $\begin{array}{l}\text { Bahasan dan analisis ttg kemampuan membayar hutang dan tk } \\
\text { kolektibilitas piutang }\end{array}$ & $\begin{array}{l}\text { 1. Penjelasan ttg kemampuan membayar } \\
\text { hutang } \\
\text { 2. Penjelasan ttg tk kolektibilitas membayar } \\
\text { hutang }\end{array}$ & $0-2 / 2$ \\
\hline 4 & $\begin{array}{l}\text { Bahasan dan analisis ttg info keu yg telah dilaporkan yang } \\
\text { mengandung kejadian yang sifatnya luar biasa \& jarang terjadi } \\
\text { (jika dpt diterapkan) }\end{array}$ & & $0-1$ \\
\hline 5 & $\begin{array}{l}\text { Analisis ttg perubahan pendapatan \& faktor-faktor yang } \\
\text { mempengaruhi }\end{array}$ & & $0-1$ \\
\hline 6 & Strategi/kebijakan bidang keuangan & & $0-1$ \\
\hline 7 & Uraian ttg aspek pemasaran & $\begin{array}{ll}\text { 1. } & \text { Pangsa Pasar } \\
\text { 2. } & \text { Analisis Pesaing } \\
\text { 3. } & \text { Jaringan pemasaran }\end{array}$ & $0-3 / 3$ \\
\hline 8 & Strategi/kebijakan bidang pemasaran & & $0-1$ \\
\hline 9 & $\begin{array}{l}\text { uraian ttg prospek usaha perusahaan-sehubungan dg industri, } \\
\text { ekonomi scr umum, \&/ pasar internasional }\end{array}$ & & $0-1$ \\
\hline 10 & $\begin{array}{l}\text { informasi dan fakta material yg terjadi setelah tgl lap akt. (jika } \\
\text { dpt diterapkan) }\end{array}$ & & $0-1$ \\
\hline 11 & $\begin{array}{l}\text { Pernyataan mengenai kebijakan dividen } \& \text { tgl serta jumlah } \\
\text { dividen kas per saham } \& \text { jumlah dividen per tahun yg } \\
\text { diumumkan a/ dibayar selama } 2 \text { tahun buku terakhir }\end{array}$ & $\begin{array}{l}\text { 1. Besarnya dividen untuk masing-masing } \\
\text { tahun } \\
\text { 2. Besarnya payout ratio }\end{array}$ & $0-2 / 2$ \\
\hline 12 & Realisasi penggunaan dana hasil penawaran umum & $\begin{array}{l}\text { 1. Total perolehan dana } \\
\text { 2. Rencana penggunaan dana } \\
\text { 3. Rincian penggunaan dana }\end{array}$ & $0-5 / 5$ \\
\hline
\end{tabular}

200 (C) 2018 The Authors. Jurnal Siasat Bisnis. Published by The Management Development Centre, Department of Management, Faculty of Economics, Universitas Islam Indonesia 


\begin{tabular}{|c|c|c|c|}
\hline & & $\begin{array}{l}\text { 4. Saldo } \\
\text { 5. Perubahan penggunaan dana (jika ada) }\end{array}$ & \\
\hline 13 & $\begin{array}{l}\text { Info material mengenai: investasi, ekspansi, divestasi, akuisisi, } \\
\text { restrukturisasi hutang/modal, transaksi yg mengandung } \\
\text { benturan kepentingan dan sifat transaksi dg pihak afiliasi (jika } \\
\text { dpt diterapkan) }\end{array}$ & & $0-1$ \\
\hline 14 & $\begin{array}{l}\text { Uraian mengenai perubahan peraturan perundang-undangan yg } \\
\text { berpengaruh signifikan thd perush (jika dpt diterapkan) }\end{array}$ & & $0-1$ \\
\hline 15 & Uraian mengenai perubahan kebijakan akuntansi & & $0-1$ \\
\hline 16 & Proyeksi jumlah penjualan tahun berikutnya & & $0-1$ \\
\hline 17 & proyeksi jumlah laba tahun berikutnya & & $0-1$ \\
\hline 18 & Proyeksi aliran kas tahun berikutnya & & $0-1$ \\
\hline E & Tata Kelola Perusahaan (Good Corporate Governance) & & $0-4 / 4$ \\
\hline 1 & Uraian Dewan Komisaris (DK) & $\begin{array}{l}\text { 1. Uraian pelaksanaan tugas DK } \\
\text { 2. Pengungkapan prosedur penetapan \& } \\
\text { besarnya renumerasi anggota DK } \\
\text { 3. Frekuensi pertemuan } \\
\text { 4. } \\
\text { Tingkat kehaditan DK dlm pertemuan } \\
\end{array}$ & \\
\hline 2 & Uraian Direksi & $\begin{array}{l}\text { 1. Ruang lingkup pekerjaan \& tgjwb masing- } \\
\text { masing anggota Direksi } \\
\text { 2. Pengungkapan prosedur penetapan \& } \\
\text { besarnya renumerasi anggota direksi } \\
\text { 3. Frekuensi pertemuan } \\
\text { 4. Tingkat kehadiran anggota direksi dlm } \\
\text { pertemuan } \\
\text { 5. Program pelatihan dlm rangka } \\
\text { meningkatkan kompetensi direksi }\end{array}$ & $0-5 / 5$ \\
\hline 3 & Komite Audit (KA) & $\begin{array}{l}\text { 1. Nama, jabatan, dan riwayat hidup singkat } \\
\text { anggota KA } \\
\text { 2. Uraian tugas dan tgjwb } \\
\text { 3. Frekuensi pertemuan \& tk kehadiran KA } \\
\text { 4. Laporan singkat pelaksanaan kegiatan } \\
\text { komite audit } \\
\text { 5. Independensi anggota KA } \\
\end{array}$ & $0-5 / 5$ \\
\hline 4 & Komite Nominasi dan Remunerasi (KNR) & $\begin{array}{l}\text { 1. Nama jabatan dan riwayat hidup singkat } \\
\text { anggota KNR } \\
\text { 2. Uraian tugas dan tgjwb } \\
\text { 3. Frekuensi pertemuan \& tk kehadiran KNR } \\
\text { 4. Uraian pelaksanaan kegiatan KNR } \\
\text { 5. Independensi anggota komite } \\
\end{array}$ & $0-5 / 5$ \\
\hline 5 & $\begin{array}{l}\text { Komite-komite lain yang lain dimiliki oleh perusahaan (jika dpt } \\
\text { diterapkan) }\end{array}$ & $\begin{array}{l}\text { 1. Nama, jabatan dan riwayat hidup singkat } \\
\text { anggota komite lain } \\
\text { 2. Uraian tugas dan tgjwb } \\
\text { 3. Frekuensi pertemuan \& tk kehadiran } \\
\text { 4. Uraian pelaksanaan kegiatan } \\
\text { 5. Independensi anggota komite } \\
\end{array}$ & $0-5 / 5$ \\
\hline 6 & Uraian tugas dan fungsi sekretaris perusahaan & $\begin{array}{l}\text { 1. Nama \& riwayat jabatan singkat sekretaris } \\
\text { perusahaan } \\
\text { 2. Uraian pelaksanaan tugas }\end{array}$ & $0-2 / 2$ \\
\hline 7 & $\begin{array}{l}\text { Uraian mengenai pelaksanaan pengawasan \& pengendalian } \\
\text { intern (SPI) }\end{array}$ & $\begin{array}{ll}\text { 1. } & \text { Informasi ttg keberadaan SPI (auditor } \\
\text { internal) } \\
\text { 2. Penjelasan ttg Aktivitas SPI } \\
\text { 3. Penjelasan ttg pengendalian internal } \\
\text { perusahaan. }\end{array}$ & $0-3 / 3$ \\
\hline 8 & Uraian mengenai manajemen risiko perusahaan & $\begin{array}{l}\text { 1. penjelasan ttg risiko-risiko yg dihadapi } \\
\text { perusahaan } \\
\text { 2. Upaya untuk mengelola risiko tersebut }\end{array}$ & $0-2 / 2$ \\
\hline 9 & Uraian mengenai tanggung jawab sosial perusahaan (CSR) & 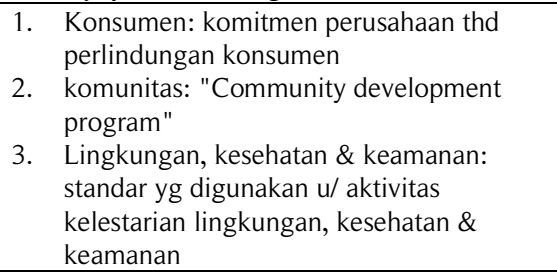 & $0-3 / 3$ \\
\hline 10 & Uraian mengenai karyawan perusahaan & $\begin{array}{l}\text { 1. Jumlah karyawan } \\
\text { 2. Pelatihan/pendidikan karyawan }\end{array}$ & $0-5 / 5$ \\
\hline
\end{tabular}


Pengaruh luas pengungkapan informasi, konsentrasi kepemilikan dan diversifikasi pada biaya modal ekuitas: studi pada perusahaan non-keuangan di indonesia

\begin{tabular}{|c|c|c|c|}
\hline & & $\begin{array}{l}\text { 3. Kondisi kesehatan \& keselamatan dlm } \\
\text { linkungan kerja } \\
\text { 4. Kebijakan rekruitmen tenaga kerja } \\
\text { 5. Tingkat perputaran karyawan }\end{array}$ & \\
\hline 11 & $\begin{array}{l}\text { Perkara penting yg sedang dihadapi oleh perusahaan, anggota } \\
\text { direksi \& anggota DK yg sdg menjabat (jika dapat diterapkan) }\end{array}$ & $\begin{array}{l}\text { 1. Pokok perkara/gugatan } \\
\text { 2. Kasus posisi } \\
\text { 3. Status penyelesaian perkara/gugatan } \\
\text { 4. Pengaruhnya thd kondisi keuangan } \\
\text { perusahaan } \\
\end{array}$ & $0-4 / 4$ \\
\hline 12 & Akses informasi dan data perusahaan & $\begin{array}{l}\text { Uraian mengenai tersedianya akses informasi } \\
\text { dan data perusahaan kpd publik, misalnya } \\
\text { melalui website, media massa, mailing list, } \\
\text { buletin, dsb }\end{array}$ & $0-1$ \\
\hline 13 & Etika Perusahaan & $\begin{array}{l}\text { 1. Keberadaan code of conduct } \\
\text { 2. Penyebaran code of conduct kpd karyawan } \\
\text { \& upaya penegakkannya. } \\
\text { 3. Persyaratan mengenai budaya perusahaan } \\
\text { (corporate culture) yang dimiliki } \\
\text { perusahaan. }\end{array}$ & $0-3 / 3$ \\
\hline
\end{tabular}

